\title{
The Development of Practical Item Analysis Program for Indonesian
} Teachers

\author{
Ali Muhson \\ Yogyakarta State University, Indonesia, alimuhson@uny.ac.id \\ Barkah Lestari \\ Yogyakarta State University, Indonesia, barkahlestari@uny.ac.id

\section{Supriyanto} \\ Yogyakarta State University, Indonesia, supriyanto@uny.ac.id \\ Kiromim Baroroh \\ Yogyakarta State University, Indonesia, kiromim_b@ uny.ac.id
}

Item analysis has essential roles in the learning assessment. The item analysis program is designed to measure student achievement and instructional effectiveness. This study was aimed to develop item-analysis program and verify its feasibility. This study uses a Research and Development (R \& D) model. The procedure includes designing and developing a product, validating, and testing the product. The data were collected through documentations, questionnaires, and interviews. This study successfully developed item analysis program, namely AnBuso. It is developed based on classical test theory (CTT). It was practical and applicable for Indonesian teachers to analyse test items.

Key Words: feasibility, item-analysis program, AnBuso, development, practical item, teachers

\section{INTRODUCTION}

Learning processes determine the quality of education. This implies that teachers have a very central role in improving the quality of education. They have crucial roles not only in designing and implementing but also in assessing the learning processes and their outcomes. Improving the quality of learning and assessment system is one of the efforts to improve the quality of education.

Learning and assessments can be said to be 'two sides of the same coin' (Guliker, Bastianes, \& Kirschner, 2004). All forms of assessment are essential components of teaching (Russell \& Airasian, 2012) and they have strong influences on the quality of 
learning (Raymond, Homer, Smith, \& Gray, 2012). Assessments involve not only finding out what students have learned but also improving the processes of learning and teaching (Bers, 2008). This implies that assessments have essential roles in improving not only the learning processes but also the learning outcomes. Good assessments will encourage teachers to determine appropriate instructional strategies and motivate students to study harder.

An assessment is a process of gathering evidence of student learning to inform instructional decisions (Stiggins \& Chappuis, 2012). It means that teachers have to gather accurate evidence of the achievements of their students as the quality and impacts of their instructional decisions depend on it. The development of assessment instruments should therefore measure all aspects of learning objectives. Good students should attain better scores than the poor ones.

The implementation of the new curriculum, known as the 2013 curriculum, in the secondary education levels in Indonesia is facing many problems (Republika, 2014), for example the difficulty of changing teachers' mind-set (Metronews, 2014; Tempo, 2013). A study reported that 87 percent of Indonesian teachers had difficulties in understanding the implementation of authentic assessments (Susilowati, 2013) as the assessment system includes too many aspects that must be measured (Tempo, 2014). It means that their ability to perform good assessments has to be improved.

An assessment is a systematic process of providing credible evidence of resources, implementation, and learning outcomes with the purpose of improving and developing effective instruction, programs, and services in higher education (Banta \& Palomba, 2014). Thus, it is a process of gathering information about the students and in turn the information is employed to make instructional decisions and improve learning processes.

An assessment should be able to assess students' progress. Such information can be used as a basis for identifying the students' status in the group and determining the next steps of learning. Therefore, the assessment has to be able to assess their competence accurately. Assessments help teachers clarify the goals and the purposes of their teaching, create learning experiences in real-life contexts, and provide many different ways for students to demonstrate their abilities and skills (Darling-Hammond, 2014). Properly used assessment procedures can contribute directly to the improvement of learning, such as (1) clarifying the nature of the intended learning outcomes, (2) providing short-term goals to work toward, (3) providing feedback concerning learning progress, (4) providing information for overcoming learning difficulties and for selecting future learning experiences, and (5) identifying the next instructional goal (Miller, Linn, \& Gronlund, 2009).

The purposes of assessments include establishing a classroom that supports learning, planning and conducting instruction, placing students, providing feedback, diagnosing student problems and disabilities, and summarizing and grading academic learning and progress (Russell \& Airasian, 2012). Thus, assessments are used to monitor the learning progress, provide information as a basis for giving feedback, and improve learning. 
To provide accurate information, assessments have to be based on several criteria, such as valid, reliable, competence focused, comprehensive, objective, and educative (Puskur, 2008). The three concepts — validity, reliability, and objectivity - have to do with the quality of the information obtained from tests or other assessment instruments or methods (Anderson, 2003; Kubiszyn \& Borich, 2013). Thus, the validity and reliability are important parts of assessments to obtain appropriate and accurate information.

Item analyses play a somewhat more important role in the construct and predictive validation (Nunnally \& Bernstein, 1994). Item analysis is the process of examining the students' responses to each test item, to judge the quality of the item (Mehrens \& Lehmann, 1991). There are two approaches to analyze item for the test development, the Classical Test Theory (CTT) and Item Response Theory (IRT) (Crocker \& Algina, 2008). They use difficulty level and discriminant index to determine the item quality. It means that the item analysis is an important process, which determines the validity of items and therefore it has an important role in identifying good items. The assessment results also provide accurate information about students' abilities therefore they can help teachers to identify which materials are difficult. The item analysis also provides information about the materials that have not been mastered by the students so that teachers can plan remedial activities. Based on the reasons it is necessary to develop practical program that can help teachers analyse items practically.

There are many software that develop to analyze item, based on either CTT or IRT, such as ITEMAN (Berk \& Griesemer, 1976) based on CTT, and BILOG-MG, MULTILOG, PARSCALE and TESTFACT based on IRT (Croudace, Ploubidis, \& Abbot, 2005). However, they have not been used optimally yet by Indonesian teachers because most software uses foreign languages which are difficult for them to understand. Some software is also less practical and applicable because it produces output with different formats. Therefore, it is necessary to develop more practical and applicable software that can cater for their needs. This present study aims to develop item analysis software or program that could be used by Indonesian teachers to prepare learning administration reports. It is named AnBuso. It is a program developed in Microsoft Excel. This program uses features, functions and formulas available on Microsoft Excel, so it only works with Microsoft Excel.

AnBuso is developed based on CTT. CTT has dominated the area of standardized testing and an advantage with CTT is relatively easy to interpret (Wiberg, 2004). CTT assumed that the observed score is seen as an estimate of the true scores plus/minus some unobservable measurement error (Allen \& Yen, 1979; Crocker \& Algina, 2008; Hambleton \& Swaminathan, 1985).

CTT uses the difficulty level and discriminant index to determine the quality of the item. Item difficulty is the percentage of students who answer an item correctly. Generally, item difficulties of about .3 to .7 maximize the information the test provides about differences among examinees (Allen \& Yen, 1979: 121; Kaplan \& Saccuzzo, 2005: 170). Item discrimination refers to the ability of an item to differentiate among students. The item discrimination index provided by AnBuso is a Pearson Product Moment 
correlation between item score and total scores. This index is the equivalent of a pointbiserial coefficient in this application. Arbitrary interpretations have been made on ranges of values of the point-biserial correlation. They range from Very Good items $(>0.40)$, Good items $(<0.39$, >0.30), Fair/marginal items $(<0.29,>0.20)$, Nondiscriminating/poor items $(<0.19,>0.00)$, Need attention $(<0.00)$ (Alagumalai \& Curtis, 2005: 8; Ebel \& Frisbie, 1991: 232; Crocker \& Algina, 2008: 315). It means that the item with correlation coefficient less than 0.2 has to be rejected. Based on these criteria, an item is considered good if it has difficulty index between 0.3 to 0.7 and item discriminant coefficient more than 0.2. AnBuso uses these criteria to judge a good or poor item.

\section{METHOD}

This study uses a model of Research and Development ( $R \& D)$. The procedure includes designing and developing a product, validating, and trying the product. A preliminary study was carried out to determine the ability and willingness of teachers to use item analysis and identify their real needs. The next step was designing a model of application program and its guidebook, which were validated by experts and revising them in order to obtain validated products.

The product validation was conducted using the Delphi method. This validation processes also involved some experts in education, measurements and computer programming. The testing of the trial products were conducted twice: limited and extended testing. The test was to obtain comprehensive information and input from users. The results show that all the instruments, the program and its guidebook are feasible to use although there are some suggestions for revision. The results of this test were also used to improve the quality of the products so that they are ready to be disseminated widely.

The study involved 65 respondents comprising teachers and school supervisors from five districts in Yogyakarta (DIY). Purposive sampling was carried out to select the respondents with computer literacy, especially the ability to operate Microsoft Excel program.

Observation, documentation, questionnaires, and interviews were employed to elicit the research data. Observation was conducted to obtain data or information about the teachers' ability to use the application program that has been developed. The data of instruments used to measure students' abilities, such as formative and summative tests were obtained by documentation techniques. The elicited documents took the forms of final examination tests, daily tests, remedial programs, and the results of the previous item analysis used by the teachers. 
Table 1

Feasibility Categories

\begin{tabular}{cll}
\hline No & Score & Category \\
\hline 1 & More than M + 1,8 SD & Very feasible \\
\hline 2 & $\mathrm{M}+0,6$ SD to M + 1,8 SD & Feasible \\
\hline 3 & $\mathrm{M}-0,6 \mathrm{SD}$ to $\mathrm{M}+0,6 \mathrm{SD}$ & Fair \\
\hline 4 & $\mathrm{M}-1,8$ SD to M $-0,6 \mathrm{SD}$ & Less feasible \\
\hline 5 & Less than $\mathrm{M}-1,8 \mathrm{SD}$ & Not feasible \\
\hline
\end{tabular}

The questionnaire elicited feedback or suggestion from teachers, supervisors, education department officers, and education experts. The questionnaire was also developed to measure the feasibility of the program concerning its visual display, contents, usefulness, practicality, and convenience. Interviews were conducted to teachers, supervisors, education department officers, and experts to obtain information regarding the strength and drawbacks of the AnBuso program.

The data were analysesed descriptively and supported by tables and graphs. Five scales of categories were employed to measure the feasibility of the program (see Table 1).

\section{FINDINGS}

The study involved 65 participants comprising teachers, supervisors and education actors. Most of them (72\%) were teachers of high schools (SMA, SMK, and MA). Many of them (68\%) were teachers of public schools and $57 \%$ were government employees. Respondents came from various fields of study, including Economics, Accounting, Mathematics, Social Studies, English, Indonesian, Information Technology, Chemistry, Physics, Biology, Geography, Arabic, and so on.

The willingness of the teachers to analyze test items was low (57\%). Only $11 \%$ of them regularly conducted test item analysis, $20 \%$ of them often did it and $12 \%$ of them never did it. It would be important to assess why the teachers had a low willingness to analyze test items.

In general, the teachers would perform item analysis if the supervisors ordered them to do so. It means that their awareness to perform item analysis was very low. This is because they were unable to use the available program. Of course this contributed to the poor quality of test items they have developed.

This study successfully developed AnBuso program and its manual book. AnBuso was developed on Microsoft Excel program. It has been improved based on the feedback from the respondents of the present research. The AnBuso was accompanied with a manual book in Indonesian language that will help teachers take advantage of the program. It provides step-by-step instructions which are very practical for the teachers to operate the program. The book contains an introduction, contents, input and data report.

The program has undertaken some important modifications in order to be compatible with the assesments system of the 2013 curriculum. Some revisions were conducted to 
improve its visual display, Input01 spreadsheet, Participant Reports spreadsheet, Participant Remedial spreadsheet, and formula changes. The modifications on the visual displays had to be done because it had too many color variations, which have made the application less attractive. The adjustments were done not only on the input spreadsheet, but also on the report spreadsheet (see Figure 1). They were made based on the respondents' feedback.

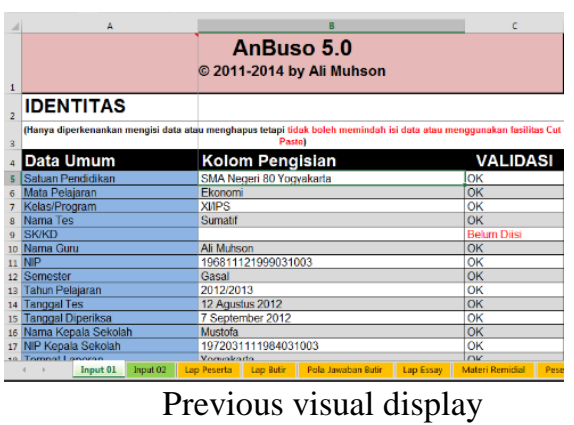

Figure 1

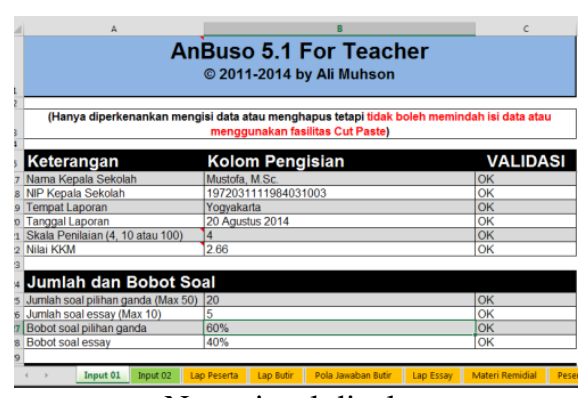

New visual display

The spreadsheet of Input01 before and after modifications

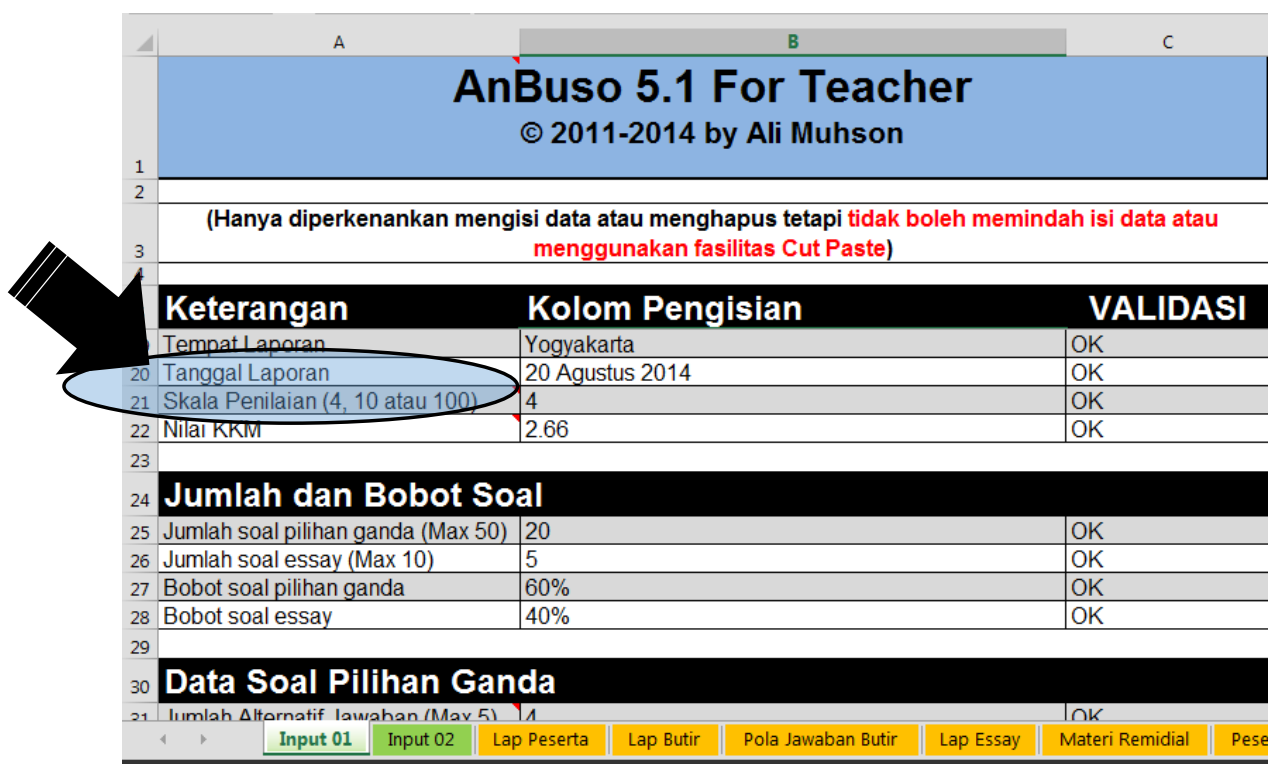

Figure 2

Grade revision

AnBuso has been adjusted to assessment system of the 2013 curriculum of the secondary education levels in Indonesia so that it accommodates Indonesian teachers' 
needs. Some amendments were also made on the assessment scales. In the previous model, the grading scales were 1-10 and 1-100. To cater for the assessments system of the 2013 curriculum, the new model provides a 1-4 grade scale (see Figure 2).

Basically the purpose of the item analysis is to determine the quality of the test items and obtain information about the assessment results so that teachers can make a followup plan such as remedial and enrichment teaching. The program also provides information about the students who are included in the remedial and enrichment group.

Figure 3 shows the general overview of the AnBuso system. Basically the program is divided into three components: input, process and output. Data input consists of Input 01 which takes general data, and Input 02 which contains the identity of students and their answers. The data entered into the Input 01 spreadsheet include the School Name, Subject, Class/Program, Name of test, SK/KD, Name of the Teacher, Teacher's NIP, Semester, Academic Year, Test Date, Inspected Date, name of the school Principal, Principal's NIP, Reporting Place, Reporting Date, Grades (10 or 100), the score of Minimum competence criteria (KKM), Objective Test Data, and Essay Test Data. The data entered into the Input 02 spreadsheet include Students Name, Gender ( $\mathrm{M}=$ Male, $\mathrm{F}=$ Female), Multiple Choice Answer Sheet, and Essay Score. Whenever the data are entered in the input 01 and input 02 spreadsheets, the program will automatically generate a complete report consisting of:

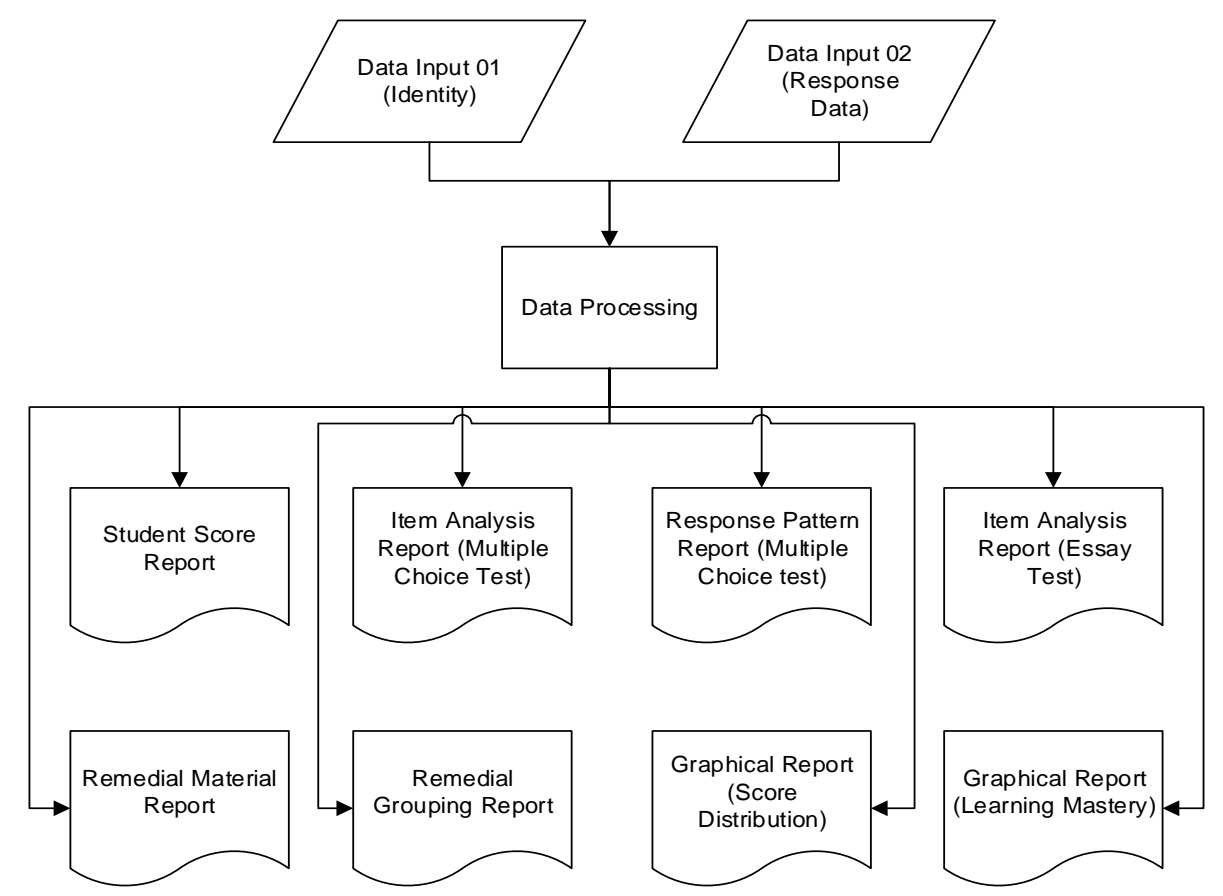

Figure 3

Flowchart Diagram Revision 
1. Student Report Sheet which displays list of test scores. The list contains the name of student and gender, number of items answered correctly and incorrectly, objective test score, essay test score, final score, and description (passed and failed), The other information in this sheet is the total number of the students, the number (percentage) of students who passed the tests, the minimum scores, maximum scores, average scores, and the standard deviation.

2. Item Report Sheet which shows the result of Multiple Choice Analysis. It contains Discriminant Index, levels of difficulty, Malfunction Distractors, and Conclusion of item in multiple choice test.

3. Response Pattern Report Sheet which contains Distribution of the answers of Multiple Choice tests.

4. Essay Report Sheet that contains Discriminant Index, levels of difficulty, and Conclusion of item in essay test.

5. Remedial Material Reports Sheet which contains materials for Individual and Classical Remedial tests.

6. Remedial Group Reports Sheet which contains the grouping of participants who take remedial tests.

7. Graphics Sheet which contains charts of minimum competence criteria (KKM) score distributions, and the proportions of the learning mastery.

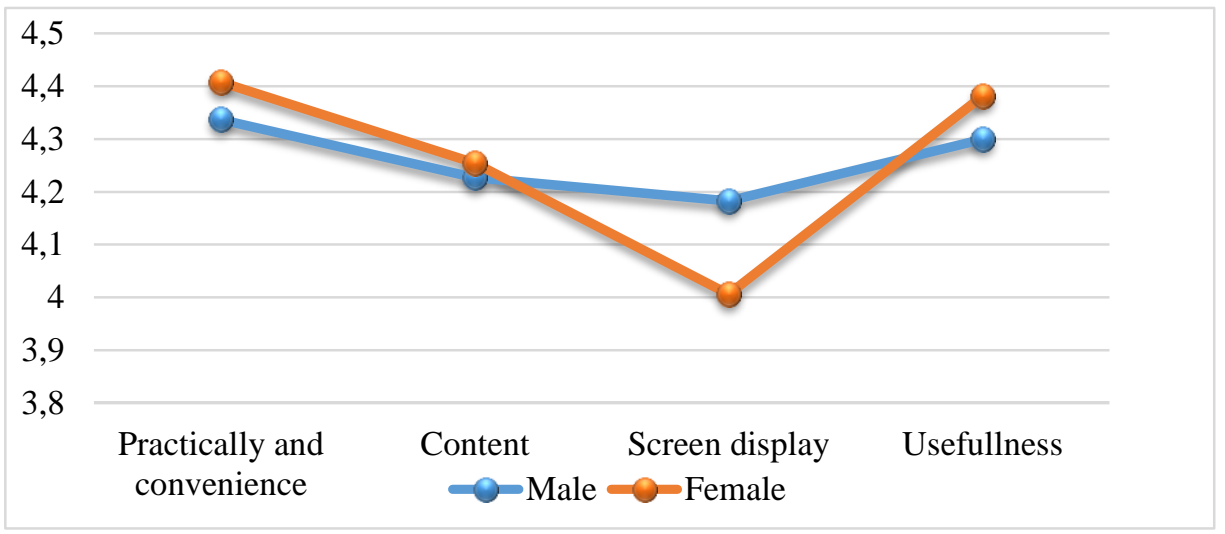

Figure 4

The results of the feasibility test

The results of the feasibility test showed that AnBuso program, developed in this study, was considered very feasible by the respondents. Of the total respondents, $51 \%$ said that it is feasible, $46 \%$ stated it is very feasible and the rest stated it is quite feasible. This shows that the program has a high usefulness in helping teachers perform item analysis. 
The aspect that gets the highest score is its practicality or convenience, and usefulness. The lowest rated aspect is the visual graphic display (see Figure 4). As the respondents reported, the AnBuso is very practical to assist them analysing test items and it really provides them with complete information. The program is able to analyze not only multiple choice test but also essay tests. The results of the test-item analysis are presented in the forms of report, therefore it is very easy for teachers to interpret them.

\section{CONCLUSION}

This study successfully developed AnBuso based on CTT, which can be used by Indonesian teachers to analyse items practically. It is developed on Microsoft Excel program. It contains data input spreadsheet, data processing spreadsheet, and analysis report sheet in tables and chart. AnBuso is considered as very feasible program regarding its practicality and convenience, usefulness, and contents, while its screen display is considered only feasible. As AnBuso is very feasible and very useful, it should be disseminated more widely to Indonesian teachers. It needs to be upgraded periodically in order to fulfil teachers' future need.

\section{REFERENCES}

Alagumalai, S. \& Curtis, D.D. (2005). Classical test theory. Alagumalai, S., et.al. (Eds.). Applied rasch measurement: A book of exemplars. Norwell, MA: Springer.

Allen, M.J., \& Yen, W.M. (1979). Introduction to measurement theory. Monterey, California: Brookd/Cole Publishing Company.

Anderson, L.W. (2003). Classroom assessment: enhancing the quality of teacher decision making. New Jersey: Lawrence Erlbaum Associates, Inc.

Banta, T.W., \& Palomba, C.A. (2014). Assessment essentials: Planning, implementing, and improving assessment in higher education. San Fransisco: Jossey-Bass.

Berk, R.A. \& Griesemer, H.A. (1976). Iteman: An item analysis program for tests, questionnaires, and scales. Educational and Psychological Measurement, 36, 189-191

Bers, T.H. (2008). The role of institutional assessment in assessing student learning outcomes. New Directions for Higher Education, 141, 31-39.

Crocker, L \& Algina, J. (2008). Introduction to classical and modern test theory. Ohio: Cengage Learning.

Croudace, T., Ploubidis, G. \& Abbot, R. (2005). BILOG-MG, MULTILOG, PARSCALE and TESTFACT: 4 programs on CD with single volume manual combining reference guide and users guide (program examples: Input and output). British Journal of Mathematical and Statistical Psychology, 58, 193-195.

Darling-Hammond, L. (2014). Next generation assessment: Moving beyond the bubble test to support 21 st century learning. San Fransisco: Jossey-Bass.

Ebel, R.L. \& Frisbie, D.A. (1991). Essential of educational measurement (5th Edition). New Delhi: Prentice-Hall, Inc. 
Guliker, J.T., Bastianes, T.J., \& Kirschner, P.A. (2004). A five-dimensional framework for authentic assessment. Educational Technology Research and Development, 52(3), 67-86.

Hambleton, R.K. \& Swaminathan, H. (1985). Item response theory. Boston, MA : Kluwer Inc.

Kaplan, R.M. \& Saccuzzo, D.P. (2005) Psychological testing: Principles, applications, and issues, 6th edition. Belmont, CA: Thomson Wadsworth.

Kubiszyn, T., \& Borich, G.D. (2013). Educational testing and measurement: classroom application and practice (10th Ed.). New Jersey: John Wiley \& Sons, Inc.

Mehrens, W.A. \& Lehmann, I.J. (1991). Measurement and Evaluation in Education and Psychology, (4th Ed.), Orlando, FL: Harcourt Brace Jovanovich.

Metronews. (2014). Ini delapan masalah dalam implementasi kurikulum 2013. Retrieved October 19, 2014, from Metronews: News.metronews.com.

Miller, M.D., Linn, R.L., \& Gronlund, N.E. (2009). Measurement and assessment in teaching (10th edition). New Jersey: Pearson Education Inc.

Nunnally, J.C., \& Bernstein, I.H. (1994). Psychometric theory (3th edition). New York: McGraw-Hill, Inc.

Puskur. (2008). Model penilaian kelas kurikulum berbasis kompetensi. Jakarta: Balitbang Depdiknas.

Raymond, J.E., Homer, C.S., Smith, R., \& Gray, J.E. (2012). Learning through authentic assessment: An evaluation of a new development in the undergraduate midwifery curriculum. Nurse Education in Practice, 13(5), 471-476.

Republika. (2014). Implementasi kurikulum 2013 masih dibayangi banyak masalah. Retrieved November 18, 2014, from Republika: www.republika.co.id.

Russell, M.K., \& Airasian, P.W. (2012). Classroom assessment: concepts and applications (7th Ed.). New York: McGraw-Hill.

Stiggins, R.J., \& Chappuis, J. (2012). An introduction to student involved assessment for learning (6th Ed). Boston: Pearson assessment training institute.

Susilowati. (2013). Kurikulum 2013, 87 persen guru kesulitan cara penilaian. Retrieved November 18, 2014, from UNNES: http://unnes.ac.id.

Tempo. (2013). Problematika implementasi kurikulum 2013. Retrieved July 10, 2013, from Tempo: www.tempo.co.

Tempo. (2014). Kurikulum 2013, Apa Saja Kendalanya? Retrieved August 16, 2014, from Tempo: www.tempo.co.

Wiberg, M. (2004). Classical test theory vs. Item response theory: an evaluation of the theory test in the Swedish driving-license test. UMEA Universitet. 


\section{Turkish Abstract Endonezyalı Öğretmenler İçin Uygulamalı Madde Analizi}

Madde analizi öğrenmenin değerlendirilmesinde önemli bir role sahiptir. Madde analiz programı eğitimin etkililiğini ve öğrenci başarısını ölçmek için uygulanır. Bu çalışma bir madde analiz programı geliştirerek programın uygulanabilirliğini öçmeyi amaçlamıştır. Çalışmada, Araştırma ve Geliştirme (R\&D) modeli kullanılmıştır. İşlem basamakları, ürün dizaynı ve geliştirilmesi, ürünün onaylanması ve test edilmesi aşamalarından oluşmaktadır. Veriler belgeleme, anketler ve görüşmeler yoluyla toplanmıştır. Bu çalışmada, başarılı bir şekilde AnBuso adı verilen klasik test teorisine (CTT) dayalı bir madde analiz programı geliştirilmiştir. Program Endonezyalı öğretmenlerin madde analizi yapmaları için uygun ve uygulanabilir bulunmuştur.

Anahtar Kelimeler: uygunluk, madde analiz programı, AnBuso, öğretmenler, öğrenmenin değerlendirilmesi, öğrenci başarısı, eğitimin etkililiği

\section{French Abstract \\ Le Développement de Programme d'Analyse d'Article Pratique pour Professeurs indonésiens}

L'analyse d'article a des rôles essentiels dans l'évaluation apprenant. Le programme d'analyse d'article est conçu pour mesurer l'accomplissement d'étudiant et l'efficacité d'instruction. Cette étude a été visée à se développer l'analyse d'article programme et vérifie sa faisabilité. Cette étude utilise une Recherche et développement (la $\mathrm{R}$ et $\mathrm{D}$ ) le modèle. La procédure inclut la conception et le développement d'un produit, une validation et un test du produit. Les données ont été rassemblées par des documentations, des questionnaires et des entretiens. Cette étude a avec succès développé le programme d'analyse d'article, à savoir AnBuso. Il est développé basé sur la théorie classique de test (CTT). C'était pratique et applicable pour des professeurs indonésiens pour analyser des articles de test items.

Mots Clés: faisabilité, programme d'analyse d'article, AnBuso, professeurs, apprenant évaluation, accomplissement d'étudiant, efficacité d'instruction

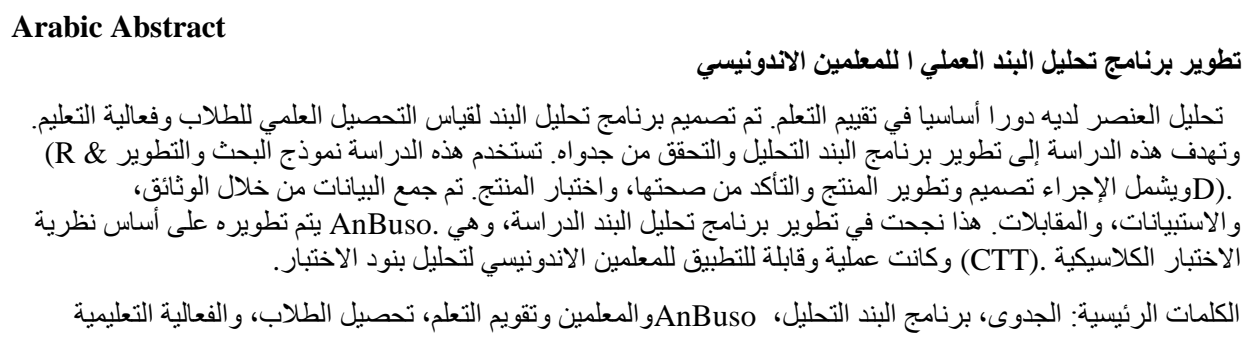




\section{German Abstract \\ Die Entwicklung des Praktischen Itemanalyseprogramms für Indonesische Lehrer}

Itemanalyse hat wesentliche Rollen in der Lernbewertung. Das Itemanalyseprogramm ist darauf ausgelegt, die Schülerleistung und die Lehrwirkung zu messen. Diese Studie zielte darauf ab, Item-Analyse-Programm zu entwickeln und seine Machbarkeit zu überprüfen. Diese Studie nutzt ein Forschungs- und Entwicklungsmodell (R \& D). Das Verfahren beinhaltet das Entwerfen und Entwickeln eines Produkts, die Validierung und das Testen des Produkts. Die Daten wurden durch Dokumentationen, Fragebögen und Interviews gesammelt. Diese Studie erfolgreich entwickelt Item Analyse-Programm, nämlich AnBuso. Es basiert auf der klassischen Testtheorie (CTT). Es war praktisch und anwendbar für indonesische Lehrer, Testartikel zu analysieren.

Schlüsselwörter: machbarkeit, item-analyse-programm, anbuso, lehrer, lernbewertung, schülerleistung, lehrwirkung

\section{Malaysian Abstract \\ Pembinaan Program Analisis Item Praktikal untuk Guru Indonesia}

Analisis item mempunyai peranan penting dalam penilaian pembelajaran. Program analisis item bertujuan untuk mengukur pencapaian pelajar dan keberkesanan pengajaran. Kajian ini bertujuan untuk membangunkan program item-analisis dan mengesahkan kemungkinan itu. Kajian ini menggunakan model penyelidikan dan pembangunan $(R \& D)$. Prosedur ini termasuk mereka bentuk dan membangunkan produk, mengesahkan, dan menguji produk. Data yang telah dikumpulkan melalui dokumen, soal selidik, dan temu bual. Kajian ini berjaya membangunkan program analisis item, iaitu AnBuso. Ia dibangunkan berdasarkan teori ujian klasik (CTT). Ia adalah praktikal dan digunakan untuk guru Indonesia untuk menganalisis item ujian.

Kata Kunci: kemungkinan, program item-analisis, AnBuso, guru-guru, penilaian pembelajaran, pencapaian pelajar, keberkesanan pengajaran

\section{Russian Abstract \\ Разработка Практического Анализа Для Индонезийских Учителей}

Анализ Анализ играет важную роль в оценке обучения. Анализ предметов предназначен для выявления успеваемости учащихся и эффективности обучения. Это исследование было направлено на разработку анализа предметов и проверку ее осуществимости. В этом исследовании используется модель исследований и разработок $(\mathrm{R} \& \mathrm{D})$. Процедура включает в себя проектирование и разработку продукта, проверку и тестирование продукта. Данные были собраны с помощью документации, анкет(вопросников) и интервью. Оно успешно разработало анализ программу, а именно AnBuso. Программа разработана на основе классической теории тестов (СТT). Это стало практичным и применимым учителями Индонезии для анализа пункт тестов.

Ключевые Слова: выполнимость, анализ программ, AnBuso, учителя, оценка обучения, успеваемость учащихся, эффективность обучения 